\title{
CORRESPONDENCE
}

\section{Heads in Bags}

SIR,--It is sad to read a scientist arguing unscientifically while he accuses another of doing the same (Nature, 236, $43 ;$ 1972). The scientific approach to any problem usually includes firstly the attempt to be impartial and objective when analysing often conflicting data; secondly the endeavour to identify and measure cause-effect relationships; thirdly in arguing from the general to the particular rather than vice versa. Let $\mathrm{Mr}$ Fakes answer three questions which spring from his evident failure to follow such principles: "the justice of overthrowing tyranny by force is . . . honourable."

(1) Is the present, reformed Ulster constitution a "tyranny" or a democracy? Compare it with other constitutions. (2) Is that "force" considered "honourable" which involves the indiscriminate, avoidable, triumphant, planned killing and maiming of men, women and children? Contrast the quantifiable results of Mafia, Klu-Klux-Klan and IRA activities. (3) How often within modern history have the practitioners of violent revolution and the associated civil warfare produced a government superior to the "tyranny" which activated their violence? Calculate the ratio of their successes to failures, comparing it with a ratio similarly derived for the exponents of constitutional reform.

Further search for political science content in Mr Fakes's emotional conclusions becomes an exercise in futility when his implicit denial of the principle of impartiality in politics--especially Irish-is used to launch a denunciation of only one side's record. As a Celt oscillating between Pantheism and agnosticism I myself have really no idea where my bias here lies. However, it is the "prejudice" of most people including Irish Republicans that the vast majority of recent atrocities have IRA origins; as yet the "Protestant backlash" has not been implicated. That reciprocating bestialities were perpetrated in the past "recent history of Ireland" is well known but irrelevant to analysing the present bloodletting, unless the atavistic principle of blood feud is invoked.

It is a sad truism that the society which wishes to survive abandons its loftier legal principles to a degree and for a duration commensurate with the particular threat to its survival. In such situations leaders ignore their sources of military intelligence with great cost to their subjects-Raglan in the Crimea, Chamberlain at Munich, Stalin's Russia 1941, Nasser's Egypt 1967, our Ulster 1972. In 1972 only a person living in a cloister could believe that moral narcissism deters the aggressor. As a contribution to political problem-solving Mr Fakes's amalgam of cloudy pontification, personal value-judgment, blatantly distorted history and political nihilism is inadequate.

$$
\begin{aligned}
& \text { Yours faithfully, } \\
& \text { O. LL. LLOYD }
\end{aligned}
$$

8 Suffolk Road,

Edinburgh 9

\section{Whither Physicists?}

SIR,-I have read with interest your editorial on "Are there jobs for physicists to do?"-and the article entitled "Where will they go?" (Nature, 236, 131 and 134; 1972).

I should like to add our experience, which is not as negative as that of Dr Swift-Hook. We believe, and have experience, that good physicists, with good class degrees, and possibly with PhDs, are very useful in both research and other activities in the company. We also think that the PhD itself does not add much to a man's suitability for industrial employment except perhaps in some branches of research. Even in research we find that people of equal ages are on the same average salary lines whether they have obtained a $\mathrm{PhD}$ or have come directly after their first degree. We also think that the university training in physics is in general a good training, and I would not like to see it much diluted.

However, we believe universities do not give students a sufficiently clear idea as to what they will do or what they will be able to do after graduating. Most physics graduates until a very few years ago could only envisage a career in research, and it is only recently that necessity has forced them to look at other jobs.

I am not certain whether the numbers of graduates in physics coming out of universities at the moment is too great for them to be absorbed in jobs requiring a knowledge of science and especially of physics. I think it probably is the case, but I have no evidence that a man who has been trained in physics is any worse at a job in engineering or administration in industry than a man trained at university in another subject such as arts or social sciences.

Yours faithfully,

\section{K. Hoselitz}

Mullard Research Laboratories,

Redhill, Surrey

\section{Expert Committees}

SIR,--I share the disappointment of your reviewer (Nature, 236, 1; 1972) over the latest report of the FAO/WHO Expert Committee on Nutrition. Vảst sums of money are spent on such UN agency reports and they do not merit the attention frequently given to them. The choice of invitees is political, rather than on the basis of scientific merit, and strongly influenced by the whims of the UN agency secretariat. When a group of virtual strangers is brought together with very little preparation for only a few days, it is too much to expect that a thorough study of the topics will result. It is usually left to the secretariat, with one or two of their friends, to write the final report. It is hardly surprising, therefore, that such reports when read serially show many inconsistencies, prejudices and glaring omissions. While the nutrition units of FAO and WHO were temporizing with "protein-rich" weaning foods, lysine fortification, nutrition rehabilitation centres, and overemphasizing the "protein gap" and kwashiorkor, private foundations were making the only significant contribution to solving the malnutrition problem of our time: the green revolution.

A fresh, hard look should be taken by the UN at its expert groups and their reports. In Britain and some other countries technical committees spend months, and if necessary a year or two, to produce reports which their governments feel they can set their seal to as representing a balanced account of the subject at that time. It is high time for the UN agencies to drop their cavalier attitude towards their responsibility of acting as spokesmen for the world on matters of practical scientific importance.

Yours faithfully, Donald S. MCLaREN

School of Medicine,

American University of Beirut, Beirut 